\title{
Assessment of Ecological Health of Sunnambar and Ariankuppam Estuaries (Southeast Coast of India)
}

\author{
S. Ajmal Khan*, P.S. Lyla, T. Sudhagar, S. Manokaran \\ Center of Advanced Study in Marine Biology, Annamalai University, Parangipettai, Tamil Nadu, \\ India \\ *seyedajmal@gmail.com
}

\begin{abstract}
Man has a long history of exploiting the costal and estuarine areas which have very high ecological values for food, transport, commerce and for settlement. Nevertheless, such ecosystems are subjected to a wide range of anthropogenic pressures which are responsible for considerable environmental impairment. Over the past decades water quality has been defined primarily in chemical terms. Recently, agencies managing water quality have been increasingly emphasising the use of biological parameters as monitoring tools for better assessment of the effects of environmental stressors on biological systems. In keeping with this emerging trend, the ecological health of two estuaries namely Sunnambar and Ariankuppam situated in the Union Territory of Puducherry on the southeast coast of India was assessed using benthic organisms. Samples were collected for a period of one year. Every month sediment samples were collected using Petersen grab. Five stations were fixed up along the course of the estuaries and each time samples were collected in duplicate. Information on physico-chemical parameter such as temperature, salinity, $\mathrm{pH}$ and organic matter was also collected. The levels of all the heavy metals analysed $(\mathrm{Co}, \mathrm{Cu}, \mathrm{Ni}, \mathrm{Pb}, \mathrm{Fe}, \mathrm{Zn}$, $\mathrm{Mn}$ and $\mathrm{Hg}$ ) were higher in Ariankuppam estuary than in Sunnambar estuary. The number of species of polychaetes identified from Sunnambar and Ariankuppam estuaries was 45 and 11 respectively. The diversity indices were very low in the Ariankuppam estuary $\left(\mathrm{H}^{\prime} \log 20.8741 \pm 0.24, \mathrm{~d}-1.07 \pm 0.45, \mathrm{~J}-0.528 \pm 0.03\right.$, Lambda' $-0.78 \pm 0.06$ and sPhi $\left.+347 \pm 77.74\right)$ and high in Sunnambar estuary (H'log2-4.1253 \pm 0.12 , d-4.982 $\pm 0.57, \mathrm{~J}-0.874 \pm 0.01$, Lambda'$0.03 \pm 0.004$ and sPhi+-1704 \pm 273.34 ). The assignment of the polychaete species identified into one of the five ecological groups (EGI: species sensitive to disturbance; EGII: species indifferent to disturbance; EGIII: species tolerant to disturbance; EGIV: second order opportunistic species; EGV: first order opportunistic species) as proposed by the marine biotic index AMBI was done based upon the list available in the AMBI program (http://www.azti.es). The M-AMBI was calculated by factor analysis (FA) of AMBI, species richness (as number of taxa) and Shannon's diversity index values, using AMBI software (http://ambi.azti.es). This method compares monitoring results with reference conditions by salinity stretch, in order to derive an M-AMBI value, which expresses the relationship between observed values and reference condition values. At 'high' status the reference condition may be regarded as an optimum where the M-AMBI approaches 1 . At 'bad' status, the M-AMBI approaches 0. High BI in Ariankuppam estuary and high M-AMBI value in Sunnambar estuary clearly revealed the disturbed condition of Ariankuppam estuary and healthy nature of Sunnambar estuary. These values (BI and M-AMBI) should be continuously monitored as there is rapid industrialisation and urbanisation around Puducherry town.
\end{abstract}

Keywords: Estuarine health, Suunambar, Ariankuppam, Macrobenthos, Diversity

Proceedings of the International Forestry and Environment Symposium 2015 of the Department of Forestry and Environmental Science, University of Sri Jayewardenepura, Sri Lanka 